\title{
Apoprotein B in Fasting
}

\section{and Postprandial Human Jejunal Mucosa}

\author{
Daniel Rachmilewitz, John J. Albers, and Davm R. Saunders \\ From the Department of Medicine and the Northwest Lipid Research Clinic, \\ University of Washington, Seattle, Washington 98195
}

A B S T R A C T We tested whether apoprotein B is present in fasting and postprandial human duodenojejunal mucosa because lipoprotein-like particles are visualized by electron microscopy within the smooth endoplasmic reticulum and the Golgi cisternae of these absorptive cells. Duodenojejunal biopsies from normal volunteers were incubated in citrate buffer and were shaken in $1 \%$ EDTA so that absorptive cells could be freed from underlying tissue. Apoprotein B was determined by double-antibody radioimmunoassay in homogenates of absorptive cells.

The preparations of absorptive cells were shown to be uncontaminated with plasma lipoproteins; they did not contain any albumin by immunodiffusion able to detect $2 \mu \mathrm{g} / \mathrm{ml}$. They adsorbed less than $0.1 \%$ of ${ }^{120} \mathrm{I}$ low density lipoprotein which was added to the citrate buffer. Cell preparations from suction biopsies of human rectum contained no detectable apoprotein $B$.

Duodenojejunal absorptive cells from 22 fasting subjects contained $3.2 \pm 0.5 \mu \mathrm{g}$ of apoprotein B per $100 \mathrm{mg}$ (wet wt) of biopsies or $1.3 \mu \mathrm{g}$ of apoprotein B per $\mathrm{mg}$ of total cell protein. The amount of apoprotein B per milligram of cell protein fell to $0.3 \mu \mathrm{g}$ in 14 of these individuals whose mucosa was also sampled $45 \mathrm{~min}$ after instilling fat intraduodenally.

These experiments provide immunochemical evidence that human duodenojejunal absorptive cells contain apoprotein $B$. This technique should be valuable for studying the physiology of intestinal lipoproteins in absorption and in patients with hyperlipidemia.

\section{INTRODUCTION}

The intestinal formation and secretion of lipoprotein is an essential part of the absorption of both dietary and endogenous fat. The intestine as a source of plasma lipo-

Received for publication 18 August 1975 and in revised form 13 November 1975. proteins was first suggested by biochemical studies which showed that the intestine could incorporate radioactive amino acids into lymph and plasma lipoproteins (1-2). Studies of the composition of intestinal lymph indicated that the intestine can produce lipoproteins other than chylomicrons (3-5). Electron microscopic studies of rats have implicated the columnar absorptive cells as the particular site involved in intestinal very low density lipoprotein (VLDL) ${ }^{1}$ production (6). In man, most of the information about the intestinal formation of lipoproteins was achieved by electron microscopic studies. In normal fasting volunteers, lipoprotein-like particles (150-650 $\AA$ diameter) were visualized within the smooth endoplasmic reticulum and the Golgi cisternae of absorptive cells covering the tips of jejunal villi. Similar particles were seen within the intercellular spaces and the lacteals $(6,7)$.

In the last few years the various lipoprotein classes have been characterized by their specific protein constituents or apolipoproteins (apoproteins). Many of these apoproteins have been isolated and characterized from human plasma and most of them are present in more than one lipoprotein family. Apoprotein B constitutes more than $95 \%$ of the protein moiety of low density lipoproteins (LDL) (8), and also represents 22 and $30-40 \%$ of the protein moieties of chylomicrons and VLDL, respectively $(9,10)$. The apoprotein $\mathbf{B}$ appears to be required for the transport of lipoprotein particles out of the absorptive cell and into the lymph. Patients suffering from abetalipoproteinemia, whose plasma lacks apoprotein B, cannot form chylomicrons after a fatty meal (11). In rats, synthesis of apoprotein B was shown in the isolated perfused intestine (12) and in a cell-free preparation of intestinal mucosa (13). In man, there are no data about the intestinal apoproteins, probably because of difficulties in obtaining suf-

\footnotetext{
${ }^{1}$ Abbreviations used in this paper: LDL, low density lipoprotein; VLDL, very low density lipoproteins.
} 
ficient samples of intestinal mucosa and lack of sensitive methods to detect small amounts of apoproteins in tissues. The aims of the present study were to test whether apoprotein B is present in fasting human duodenojejunal absorptive cells and to elucidate further the mechanisms involved in the formation of chylomicrons during fat absorption.

\section{METHODS}

Human duodenojejunal and rectal biopsies. 30 normal volunteers, aged 18-35 yr, were studied. From each volunteer, 10-20 duodenojejunal biopsies (10-12 $\mathrm{mg}$ each) were obtained with the hydraulic biopsy tube (14) after an overnight fast $(12-16 \mathrm{~h})$. In 14 of the volunteers, a fatty meal was then infused directly into the duodenum through the delivery channel of the biopsy tube. The meal consisted of $35 \mathrm{ml}$ of corn oil (Mazola, Best Foods Div., Corn Products Co., Englewood Cliffs, N. J.) blended for 2 min (Osterizer, John Oster Mfg. Co., Milwaukee, Wisc.) with $35 \mathrm{ml}$ of $0.15 \mathrm{M} \mathrm{NaCl}$. $45 \mathrm{~min}$ after instilling the fat, 8-10 more biopsies were taken. Four to five rectal biopsies were obtained from four of the volunteers with a suction biopsy tube (15). All volunteers were informed of the risks of intestinal or rectal biopsies before participation. No complications ensued. The biopsies were kept in $0.15 \mathrm{M} \mathrm{NaCl}$, $0.01 \%$ EDTA at $4^{\circ} \mathrm{C}$.

Preparation of isolated duodenojejunal absorptive cells. To free the absorptive cell from plasma and from underlying tissue, the biopsies were blotted dry, weighed, and incubated for $15 \mathrm{~min}$ at $37^{\circ} \mathrm{C}$ in a buffer containing sodium citrate $(27 \mathrm{mM}), \mathrm{KCl}(1.5 \mathrm{mM}), \mathrm{NaCl}(96 \mathrm{mM}), \mathrm{KH}_{\mathbf{2}}-$ $\mathrm{PO}_{4}(8 \mathrm{mM})$, and $\mathrm{Na}_{2} \mathrm{HPO}_{4}(5.6 \mathrm{mM})$ (16). This buffer was then discarded and the biopsies were suspended and shaken vigorously in $5.0 \mathrm{ml}$ of $0.15 \mathrm{M} \mathrm{NaCl}, 1 \%$ EDTA. Phase microscopy confirmed that this procedure released the absorptive cells from the underlying tissue, and histological sections of the remaining tissue confirmed that almost all the absorptive cells were released. The released absorptive cells were washed five times with $5.0 \mathrm{ml}$ of $0.15 \mathrm{M} \mathrm{NaCl}$, $0.01 \%$ EDTA at $4^{\circ} \mathrm{C}$.

Extraction and solubilization of the tissue lipoproteins. Three different methods were used to disrupt the cell membranes and to solubilize the lipoproteins. In the first method, the washed isolated cells were homogenized with 10 vol of $0.15 \mathrm{M} \mathrm{NaCl}, 0.01 \%$ EDTA in a whole glass conical homogenizer. The homogenate was centrifuged for $500,000 \mathrm{~g}$ $\mathrm{min}$ in an International centrifuge model B-20 (International Equipment Co., Needham Heights, Mass.). Portions of the supernate were taken for protein determination and for double-antibody radioimmunoassay for apoprotein $B$. In the second method, the isolated cells were suspended in 10 vol of $0.15 \mathrm{M} \mathrm{NaCl}, 0.01 \%$ EDTA and were sonicated twice for $30 \mathrm{~s}$ at $10 \mathrm{~W}$ in a model W-140 sonifier (Branson Sonic Power Co., Danbury, Conn.). The sonicated material was then centrifuged for $500,000 \mathrm{~g}$-min in an International centrifuge model B-20. Samples of the supernate were taken for analysis. In the third method, the isolated cells were homogenized in $10 \mathrm{vol}$ of $1 \%$ sodium cholate in $0.15 \mathrm{M} \mathrm{NaCl}, 0.01 \% \mathrm{EDTA}$ in the whole glass conical homogenizer. This homogenate was centrifuged for 500,000 $g$-min in an International centrifuge model B-20. The supernate was dialyzed for $24 \mathrm{~h}$ against several changes of $0.15 \mathrm{M} \mathrm{NaCl}, 0.01 \%$ EDTA before the determination of protein, albumin, and apoprotein B. All procedures were carried out at $4^{\circ} \mathrm{C}$.
Preparation of ${ }^{125} I-L D L$. LDL $\quad(d=1.019-1.063 \mathrm{~g} / \mathrm{ml})$ was prepared by sequential ultracentrifugation and iodinated as described previously (17). Sufficient reactants were added to give a sp act of $2 \times 10^{5} \mathrm{cpm} / \mu \mathrm{g}$.

Analytical procedures and determination of radioactivity. Apoprotein B was determined by double-antibody radioimmunoassay as recently described (17) which was modified as follows: For this study, $54 \mathrm{ng}$ of ${ }^{120} \mathrm{I}-\mathrm{LDL}$ was used in each assay tube and the incubation time was $48 \mathrm{~h}$ for the first antibody (rabbit antihuman LDL [rabbit 28, bleeding IA], diluted approximately $1: 10,000)$. Albumin was determined by a sensitive immunodiffusion method able to detect $2 \mu \mathrm{g} / \mathrm{ml}$. Protein was determined following the method of Lowry et al. (18). Radioactivity was determined by Autogamma Counter (Nuclear-Chicago, Des Plains, IIl.).

\section{RESULTS AND DISCUSSION}

Apoprotein B was $3.2 \pm 0.5 \mu \mathrm{g} / 100 \mathrm{mg}$ of wet weight in duodenojejunal absorptive cells from 22 fasting subjects. The amount of apoprotein B per $100 \mathrm{mg}$ wet weight was significantly lower in the samples obtained 45 min after the fat meal. This decrease was also apparent when the ratios of apoprotein $B$ to total protein in fasting and postprandial absorptive cells were compared (Table I).

The possibility of contamination of the isolated absorptive cells by plasma was excluded by the following experiments. First, albumin as a plasma marker could not be detected in any of the cell preparations (lower limit of detection, $2 \mu \mathrm{g} / \mathrm{ml}$ ). We could thus rule out a

TABLE I

Apoprotein B in Isolated Duodenojejunal or Rectal Cells*

\begin{tabular}{cccc}
\hline & \multicolumn{2}{c}{ Wet weight tissue } & \\
\cline { 2 - 3 } & Apoprotein B & $\begin{array}{c}\text { Total cell } \\
\text { protein }\end{array}$ & $\begin{array}{c}\text { Apoprotein } \\
\text { B /total cell } \\
\text { protein }\end{array}$ \\
\hline & $\mu g / 100 m g$ & $m g / 100 ~ m g$ & $\mu g / m g$ \\
Duodenojejunum, & & & \\
Fasting & & & \\
$22 \ddagger$ & $3.2 \pm 0.5 \S$ & $3.1 \pm 0.3$ & $1.3 \pm 0.3$ \\
& $(0.1-8.2)$ & $(1.2-5.4)$ & $(0.1-6.7)$ \\
Fed & & & \\
14 & $1.0 \pm 0.2$ & $3.2 \pm 0.3$ & $0.3 \pm 0.1$ \\
& $(0-2.2)$ & $(1.4-5.2)$ & $(0-1.0)$
\end{tabular}

Rectum

$\begin{array}{llll}4 & 0 & 0.6 \pm 0.1 & - \\ & & (0.2-0.7)\end{array}$

*Isolated cell preparations were obtained from duodenojejunal and rectal biopsies after their incubation with citrate buffer. Total protein and apoprotein B were determined in $0.15 \mathrm{M}$ $\mathrm{NaCl}, 0.01 \%$ EDTA or $1 \%$ sodium cholate in $0.15 \mathrm{M} \mathrm{NaCl}$, $0.01 \%$ EDTA homogenates of the cell preparations as described in Methods.

$\ddagger$ Number of samples tested.

$\S$ Results are mean \pm SEM with the range in parentheses.

Apoprotein B in Human Intestinal Mucosa 
plasma contamination of $0.05 \mu \mathrm{l}$ which represents a contamination of $0.05 \mu \mathrm{g}$ of apoprotein B (17). In the second experiment, the adsorption of ${ }^{125} \mathrm{I}-\mathrm{LDL}$ to the isolated human jejunal cells was tested. In three different experiments, 5.8, 11.6, and $23.2 \mu \mathrm{g}$ of ${ }^{125} \mathrm{I}-\mathrm{LDL}$ were added to the citrate buffer before incubation with 40 $\mathrm{mg}$ of duodenojejunal biopsies. The cells were isolated and washed in the usual manner, and the radioactivity present in each washing and that adsorbed by the cells after the five washings was determined. In the three experiments only $0.08-0.1 \%$ of the added ${ }^{120} \mathrm{I}-\mathrm{LDL}$ was adsorbed by the cells. From these observations one can calculate that $3.0 \mathrm{ml}$ of plasma would have had to contaminate an experiment to account for the amount of apoprotein B detected in $100 \mathrm{mg}$ of duodenojejunal biopsies. In the third experiment, radioimmunoassay for the apoprotein B was performed on homogenates of cells obtained in a similar manner from rectal biopsies of four volunteers. No apoprotein B could be detected in the cells obtained from the rectal biopsies (Table I), even though the double-antibody radioimmunoassay could detect as little as $25 \mathrm{ng}$.

The recovery, by radioimmunoassay, of added amounts of apoprotein $\mathrm{B}$ to $1 \%$ sodium cholate in $0.15 \mathrm{M} \mathrm{NaCl}$, $0.01 \%$ EDTA, or to $0.15 \mathrm{M} \mathrm{NaCl}, 0.01 \%$ EDTA was $96 \pm 7 \%$ in 10 experiments. This quantitative recovery of apoprotein B was unaffected by prior homogenization or sonication. When apoprotein B was added to washed absorptive cells and then was quantified after homogenizing, the recovery of added apoprotein was $66 \pm 5 \%$ in seven experiments. Corn oil did not alter this recovery of apoprotein B from homogenates. The recovery of apoprotein $B$ was independent of the state of the absorptive cells. When apoprotein $B$ was added to homogenates of fasting cells, the recovery was 75

TABLE II

Apoprotein B in Isolated Duodenojejunal Cells*

\begin{tabular}{ccc}
\hline $\begin{array}{c}\text { No. of } \\
\text { samples }\end{array}$ & Procedure & $\begin{array}{c}\text { Apoprotein } \\
\text { B/wet wt } \\
\text { of tissuef }\end{array}$ \\
\hline & & $\mu g / 100 \mathrm{mg}$ \\
7 & Homogenization in $0.15 \mathrm{M} \mathrm{NaCl}, 0.01 \%$ EDTA & $\begin{array}{l}3.2 \pm 1.0 \\
(0.7-8.2)\end{array}$ \\
9 & Sonication in 0.15 M NaCl, 0.01\% EDTA & $3.3 \pm 0.8$ \\
& & $(0.1-7.6)$ \\
6 & Homogenization in $1 \%$ sodium cholate in & $2.6 \pm 0.5 \S$ \\
& $0.15 \mathrm{M} \mathrm{NaCl}, 0.01 \%$ EDTA & $(1.1-4.3)$ \\
\hline
\end{tabular}

* Isolated cell preparations were obtained from fasting duodenojejunal biopsies after their incubation with citrate buffer. The cells were homogenized or sonicated in $0.15 \mathrm{M} \mathrm{NaCl}, 0.01 \%$ EDTA, or homogenized in $1 \%$ sodium cholate in $0.15 \mathrm{M} \mathrm{NaCl}, 0.01 \%$ EDTA as described in Methods. Apoprotein B was determined on the cell extracts by double-antibody radioimmunoassay.

$\ddagger$ Results are mean \pm SEM with the range in parentheses.

$\$$ Not significantly different from homogenized or sonicated with $0.15 \mathrm{M}$ $\mathrm{NaCl}, 0.01 \%$ EDTA $(P>0.05)$. $\pm 6 \%$ (three experiments) while the recovery from homogenates of postprandial cells was $77 \pm 6 \%$ in three experiments.

The incomplete recovery of apoprotein B in cell homogenates may have been caused by sedimentation of this apoprotein with cellular debris. We sought apoprotein $B$ in saline washings of sediment from either fasting or postprandial absorptive cells; none was detected. Recovery of apoprotein B was not improved by homogenizing cells in sodium cholate which should have helped to dissociate the apoprotein from cellular debris (19) (Table II).

This study provides immunochemical evidence that human duodenojejunal absorptive cells contain apoprotein $\mathrm{B}$. We wondered if the amount of apoprotein B within absorptive cells would change after a fatty meal. We elected to sample the duodenojejunal mucosa $45 \mathrm{~min}$ after infusing corn oil. Previous studies showed that, at this time interval, the lipid content of the biopsies rose (20), and that chylomicron-like particles were readily seen in intercellular spaces and lamina propria (21). The amount of apoprotein B fell by $60 \%$ in postprandial absorptive cells (Table I). Our observations suggest that, under the conditions of our fatty meal, the absorbed fat combines with preformed apoprotein B. The efflux of the apoprotein B as chylomicrons or VLDL particles into intercellular spaces and lamina propria seems to exceed the rate of de novo synthesis of this apoprotein.

The techniques used in this study should be valuable for studying the pathophysiology of intestinal apoproteins. Recently it has been suggested that lipoproteins of intestinal origin have a significant role in the pathogenesis of several hyperlipidemic conditions $(22,23)$. Quantification of the apoprotein B and possibly of other apolipoproteins in the absorptive cells of patients with hyperlipidemia may establish that the intestinal mucosa is involved in the pathogenesis of these conditions.

\section{ACKNOWLEDGMENTS}

This project was supported by research grant Am 16059 from the National Institute of Arthritis, Metabolism and Digestive Diseases, and by contract NIHVI2157A from the National Institutes of Health, Lipid Metabolism Branch.

\section{REFERENCES}

1. Roheim, P. S., L. I. Gidez, and H. A. Eder. 1966. Extrahepatic synthesis of lipoproteins of plasma and chyle: Role of the intestine. J. Clin. Invest. 45: 297300.

2. Isselbacher, K. J., and D. M. Budz. 1963. Synthesis of lipoproteins by rat intestinal mucosa. Nature (Lond.). 200: 364-365.

3. Ockner, R. K., F. B. Hughes, and K. J. Isselbacher. 1969. Very low density lipoprotein in intestinal lymph: origin, composition and role in lipid transport in the fasting state. J. Clin. Invest. 48: 2079-2088. 
4. Ockner, R. K., K. J. Bloch, and K. J. Isselbacher. 1968. Very low density lipoprotein in intestinal lymph: evidence for the presence of the A protein. Science (Wash. D. C.). 162: 1285-1286.

5. Windmueller, H. G., and R. I. Levy. 1968. Production of $\beta$-lipoprotein by intestine in the rat. J. Biol. Chem. 243: 4878-4884.

6. Jones, A. L., and R. K. Ockner. 1971. An electron microscopic study of endogenous very low density lipoprotein production in the intestine of rat and man. J. Lipid Res. 12: 580-589.

7. Tytgat, G. N., C. E. Rubin, and D. R. Saunders. 1971. Synthesis and transport of lipoprotein particles by intestinal absorptive cells in man. J. Clin. Invest. 50: 2065-2078.

8. Gotto, A. M., W. V. Brown, R. I. Levy, M. E. Birnbaumer, and D. S. Fredrickson. 1972. Evidence for the identity of the major apoprotein in low density and very low density lipoproteins in normal subjects and patients with familial hyperlipoproteinemia. J. Clin. Invest. 51 : 1486-1494.

9. Shore, B., and V. Shore. 1969. Isolation and characterization of polypeptides of human serum lipoproteins. Biochemistry. 8: 4510-4516.

10. Kostner, G., and A. Holasek. 1972. Characterization and quantitation of the apolipoproteins from human chyle chylomicrons. Biochemistry. 11: 1217-1223.

11. Isselbacher, K. J., R. Scheig, G. R. Plotkin, and J. B. Caulfield. 1964. Congenital $\beta$-lipoprotein deficiency: an hereditary disorder involving a defect in the absorption and transport of lipids. Medicine (Baltimore). 43: 347361.

12. Windmueller, H. G., P. N. Herbert, and R. I. Levy. 1973. Biosynthesis of lymph and plasma lipoprotein apoproteins by isolated perfused rat liver and intestine. $J$. Lipid Res. 14: 215-223.

13. Kessler, J. I., J. Stein, D. Dannacker, and P. Narces- sian. 1970. Biosynthesis of low density lipoprotein by cell-free preparations of rat intestinal mucosa. J. Biol. Chem. 245 : 5281-5288.

14. Flick, A. L., W. E. Quinton, and C. E. Rubin. 1961. A peroral hydraulic biopsy tube for multiple sampling at any level of the gastrointestinal tract. Gastroenterology. 40: 120-126.

15. Flick, A. L., K. F. Voegtlin, and C. E. Rubin. 1962. Clinical experience with suction biopsy of rectal mucosa. Gastroenterology. 42: 691-705.

16. Stern, B. K., and W. E. Jensen. 1966. Active transport of glucose by suspensions of isolated rat intestinal epithelial cells. Nature (Lond.). 209: 789-790.

17. Albers, J. J., V. G. Cabana, and W. R. Hazzard. 1975. Immunoassay of human plasma apolipoprotein B. Metab. Clin. Exp. 24 : 1339-1351.

18. Lowry, O. H., N. J. Rosebrough, A. L. Farr, and R. J. Randall. 1951. Protein measurement with the Folin phenol reagent. J. Biol. Chem. 193: 265-275.

19. Rachmilewitz, D., O. Stein, P. S. Roheim, and Y. Stein. 1972. Metabolism of iodinated high density lipoproteins in the rat. 2. Autoradiographic localization in the liver. Biochim. Biophys. Acta. 270: 414-425.

20. Saunders, D. R., P. O. Ways, C. M. Parmentier, and C. E. Rubin. 1966. Studies on the lipid composition of human small bowel mucosa. J. Clin. Invest. 45: 15161525

21. Rubin, C. E. 1966. Electron microscopic studies of triglyceride absorption in man. Gastroenterology. 50: 6577.

22. Mistilis, S. P., and R. K. Ockner. 1972. Effect of ethanol on endogenous lipid and lipoprotein metabolism in small intestine. J. Lab. Clin. Med. 80: 34-46.

23. DenBesten, L., R. H. Reyna, W. E. Connor, and L. D. Stegink. 1973. The different effects on the serum lipids and fecal steroids of high carbohydrate diets given orally or intravenously. J. Clin. Invest. 52: 1384-1393. 